\title{
Study of Phasic Development and Growth Attributes of Rice Cultivars at Variable Weather Condition
}

\author{
Rajan Chaudhari, Ashish Singh*, S.R. Mishra, A.K. Singh and A.N. Mishra \\ Department of Agricultural Meteorology, Narendra Deva University of Agriculture and \\ Technology Narendra Nagar, Kumarganj, Faizabad-224229 (U.P), India \\ *Corresponding author
}

\begin{tabular}{|c|c|}
\hline & A B S T R A C T \\
\hline $\begin{array}{l}\text { Ke y w or d s } \\
\text { Phenophases, } \\
\text { LGR, } \\
\text { CGR, } \\
\text { RGR. }\end{array}$ & $\begin{array}{l}\text { A field experiment was conducted during kharif season of } 2014-15 \text { at N.D. University of } \\
\text { Agriculture and Technology, Kumarganj, Faizabad (U.P.) in sandy loan soil. The } \\
\text { experiment consisted of } 9 \text { treatment combinations comprised of three transplanting dates } \\
\text { viz., July } 5\left(\mathrm{D}_{1}\right) \text {, July } 15\left(\mathrm{D}_{2}\right) \text { and July } 25\left(\mathrm{D}_{3}\right) \text { and three varieties viz., Sarjoo- } 52\left(\mathrm{~V}_{1}\right) \text {, } \\
\text { NDR-359 }\left(\mathrm{V}_{2}\right) \text { and Swarna }\left(\mathrm{V}_{3}\right) \text {. It was observed that different phenophases of rice } \\
\text { markedly varied with not only dates of transplanting but also different weather variables } \\
\text { which ultimately creates the different crop growing environment to harvest the vield }\end{array}$ \\
\hline Article Info & accordingly Among the three varieties it was also observed that different phenophases has \\
\hline $\begin{array}{l}\text { Accepted: } \\
\text { 24 January } 2017 \\
\text { Available Online: } \\
\text { 10 February } 2017\end{array}$ & $\begin{array}{l}\text { taken higher days inV } V_{1} \text { as compare to } V_{2} \text { and in different days of transplanting higher linear } \\
\text { growth rate (LGR) was recorded in } D_{2} \text { than } D_{1} \text { and } D_{3} \text {. Crop growth rate (CGR) in } V_{3} \\
\text { recorded highest CGR as compare to } V_{1} \& V_{2} . V_{3} \text { maintained the superiorly of RGR and } \\
\text { possess highest growth rate } 0.40 \mathrm{mg} / \mathrm{g} / \text { day over } V_{2}(0.36 \mathrm{mg} / \mathrm{g} / \text { day }) \text { and } V_{1}(0.29 \\
\mathrm{mg} / \mathrm{g} / \text { day). }\end{array}$ \\
\hline
\end{tabular}

\section{Introduction}

Rice yields have been increasing since the 1960s, but since the 1990s, growth in rice production has been slower than population growth Indeed, it is anticipated that rice production will need to increase by $30 \%$ by 2025 in order to sustain those who need it for sustenance. However, climate change, especially access to water, soil erosion and other problems threaten rice yields. The impact of air temperature on rice growth would be specific because of the different sensitivity of different locations with regard to temperature. In tropical regions, the temperature increase due to the climate change is probably near or above the optimum temperature range for the physiological activities of rice (Baker et al., 1992). Such warming will thus reduce rice growth. In addition, higher temperatures will cause spikelet sterility owing to heat injury during panicle emergence. In temperate regions, increased air temperatures should hasten rice development, thereby shortening the time from transplanting (or direct seeding) to harvesting and reducing the total time for photosynthesis yield development (Neue and Sass, 1994). Rice is very sensitive to higher temperature during reproductive stage especially flowering and anthesis. It is necessary to identify genetic donors for heat stress from high temperature rice growing environments. Temperature stress affects at 
reproductive stage by adopting three different planting dates with 15 days interval at different temperature regimes from 35.6 degrees $C$ (E1) to 39.2 degrees $C(E 3)$ at reproductive stage. The elevated temperature at the time of flowering and maturity determines the yield per se of the genotypes. Under high temperature stress, the response of genotypes depended on developmental stage, but highest sensitivity was recorded at reproductive stage. The time of sowing, days to flowering (duration group), heat escape (early morning flowering) and inbuilt tolerance were the crucial factors in determining the performance of genotypes to varying temperature. Hence, it is necessary to select genotypes by keeping in view the above factors for different temperature stress within and across the environment Raju et al., (2013).

\section{Materials and Methods}

The experiment comprised three different types of rice varieties Sarjoo-52, NDR-359 and Swarna at three dates of transplanting viz 5 July, 15 July and 25 July during 2014. The experiment was conducted in split plot design (SPD) and replicated the three times. The details of experiment has been described elsewhere Rajan Chaudhari 2015. The different growth parameters studied were measured as follows;

Days taken to different phenophases: Total numbers of days taken from date after transplanting to different phenophases of rice crop were recorded visually as to know the effect of various treatments on the phenophasic duration.

Linear growth rate (LGR): Linear growth rate (LGR) was calculated by using following formula.

Linear growth rate $(\mathrm{LGR})=\frac{\mathrm{L}_{2}-\mathrm{L}_{1}}{\mathrm{t}_{2}-\mathrm{t}_{1}}$
$\mathrm{L}_{1} \& \mathrm{~L}_{2}$ are the length of plant height at time $\mathrm{t}_{1} \& \mathrm{t}_{2}$ respectively.

Crop growth rate: Crop growth rate represented total dry matter productivity of the community per unit land area over a certain time spam. The crop growth rate have been calculated by using following equation given by Watson (1947) and reported as $\mathrm{kg} \mathrm{m}^{-}$ ${ }^{2}$ week $^{-1}$ or $\mathrm{kg} \mathrm{m}^{-2}$ month $^{-1}$.

$\mathrm{CGR}=\frac{\mathrm{W}_{2}-\mathrm{W}_{1}}{\mathrm{t}_{2}-\mathrm{t}_{1}} \times \frac{1}{\mathrm{~L}}$

$\mathrm{W}_{1}$ and $\mathrm{W}_{2}$ are plant dry weight of biomass at times $t_{1}$ and $t_{2} L$ is land area.

Relative growth rate: Relative growth rate was determined by measuring the plant dry weight 15 days interval of crop growth rate viz. at 30,45, 60, 75, 90 and 105 days of transplanting. It was computed by using the formula given below and expressed as mgg${ }^{1} /$ day $^{-1}$ (Red Ford, 1967).

$\mathrm{RGR}=\frac{\log 10 \mathrm{~W}_{2}-\log 10 \mathrm{~W}_{1}}{\left(\mathrm{t}_{2}-\mathrm{t}_{1}\right)}$

Where $\mathrm{W}_{1}$ and $\mathrm{W}_{2}$ are the plant dry weight at time $t_{1}$ and $t_{2}$ respectively.

\section{Results and Discussion}

Days taken to attain different phenophases of rice cultivars at different days of transplanting have been depicted in table: 1. From table it was revealed that days taken to attain maximum tillering at $\mathrm{I}^{\text {st }}$ date of transplanting on July5 $\left(\mathrm{D}_{1}\right)$, was 30 days after transplanting (DAT) while panicle initiation started at 58 days, $50 \%$ flowering at 74days, milking started at 83 days, dough at 92 days and physiological maturity at 102 DAT. At II $^{\text {nd }}$ date of transplanting on July15 $\left(\mathrm{D}_{2}\right)$, different phenophases viz. maximum tillering attained 
at $26 \mathrm{DAT}$, panicle initiation at 56 days, 50\% flowering attained in 72 DAT while milking and dough was at 80 and91 DAT respectively, followed by physiological maturity which attained in 106 days after transplanting. Similarly at III $^{\text {rd }}$ date of transplanting on July25 $\left(\mathrm{D}_{3}\right)$, for maximum tillering to physiological maturity the days taken to attain different phenophases were lower as compared to the either $\mathrm{D}_{1}$ or $\mathrm{D}_{2}$. Quantitatively the values for days taken was 25 DAT for maximum tillering, 51 DAT for panicle initiation, 67 DAT for $50 \%$ flowering, 74 DAT for milking, 85 DAT for dough and 95 days after transplanting for physiological maturity. From the table it was also observed that different phenophases has taken higher days in $D_{1}$ as compared to $D_{2}$ and $D_{3}$ except physiological maturity for which $\mathrm{D}_{2}$ has taken higher days as compare to $\mathrm{D}_{1}$.

Among the varieties, variety for Sarjoo-52 $\left(\mathrm{V}_{1}\right)$ the days taken to attain maximum tillering was 26 DAT while panicle initiation started at 52 DAT, 50\% flowering at 67 DAT, milking at 74 DAT, dough at 84 DAT and physiological maturity at 98 DAT. Similarly variety NDR- $359\left(\mathrm{~V}_{2}\right)$, has taken 24 DAT for maximum tillering, panicle initiation attained at 48 DAT, 50\% flowering at 64 DAT, milking at 72 DAT, dough at 82 DAT and physiological maturity at 89 DAT. Similarly III $^{\text {rd }}$ variety Swarna $\left(V_{3}\right)$, from maximum tillering to physiological maturity the days taken to attain different phenophases were more than the either $\mathrm{V}_{1}$ or $\mathrm{V}_{2}$ as 31 DAT took for maximum tillering against the 26 and 24 DAT for $\mathrm{V}_{1}$ and $\mathrm{V}_{2}$. Panicle initiation started at 65 DAT for $\mathrm{V}_{3}, 50 \%$ flowering at $82 \mathrm{DAT}$, milking 91 DAT, dough 102 and physiological maturity at 116 DAT. Among the three varieties it was also observed that different phenophases has taken higher days in $\mathrm{V}_{1}$ as compare to $\mathrm{V}_{2}$.

Linear Growth Rate (LGR) (cm/day): Linear Growth Rate (LGR) (cm/day) of different rice cultivars at different days of transplanting has been depicted in table $2 \&$ characteristics feature has been depicted in fig. 1.1. From table it was revealed that maximum linear growth rate at $\mathrm{I}^{\text {st }}$ date of transplanting on July5 $\left(\mathrm{D}_{1}\right)$, was $1.79 \mathrm{~cm} /$ day at 45 DAT with further decrease and increase at $75 \& 90$ DAT. At II $^{\text {nd }}$ date of transplanting on July15 $\left(D_{2}\right)$, maximum linear growth rate (LGR) was recorded $1.81 \mathrm{~cm} /$ day higher than at $\mathrm{D}_{1}$ at same 45 DAT. Similarly at III $^{\text {rd }}$ date of transplanting on July25 $\left(\mathrm{D}_{3}\right)$, linear growth rate (LGR) was lower than the either $\mathrm{D}_{1}$ or $\mathrm{D}_{2}$. Quantitatively the maximum value of LGR was recorded at 45 to 60 DAT at all dates of transplanting may be due to maximum energy translocation in to PI stage of crop hence recorded the better growth rate. From the table it was also observed that different day of transplanting has taken higher linear growth rate (LGR) in $\mathrm{D}_{2}$ than $\mathrm{D}_{1}$ and $\mathrm{D}_{3}$ may be due to congenial crop growing environment at $\mathrm{D}_{2}$ transplanting. From the significant analysis, it was evident that among dates of transplanting 45 DAT, 75 DAT, and 105 DAT were significant among each other while 30 DAT, 60 DAT and 90 DAT were nonsignificant among each other.

Among the varieties for Sarjoo-52 $\left(\mathrm{V}_{1}\right)$ the maximum $1.73 \mathrm{~cm} /$ day linear growth rate (LGR) recorded at 45 DAT with further decrease in LGR up to 75 DAT. Similarly for NDR- $359\left(\mathrm{~V}_{2}\right)$, maximum LGR1.83 cm/day was recorded at 45 DAT but higher than $V_{1}$ at same 45 DAT. Similar trend of variation for was observed as that of $V_{1}$.Similarly III $^{\text {rd }}$ variety $\mathrm{Swarna}\left(\mathrm{V}_{3}\right)$, attained maximum linear growth rate (LGR) $1.58 \mathrm{~cm} /$ day at same DAT and also followed the similar trend but possess lower value than that of $\mathrm{V}_{1} \& \mathrm{~V}_{2}$ and possess the lowest growth rate among the varieties. From the significant analysis, it was evident that varieties were significant among each other all dates of transplanting. Crop growth rate (CGR) $\left(\mathrm{gm}^{-2} \mathrm{~d}^{-1}\right)$ : Crop Growth Rate (CGR) $\mathrm{gm}^{-2} \mathrm{~d}^{-1}$ of different rice varieties 
at different days of transplanting has been depicted in table 3. From table it was revealed that maximum crop growth rate (CGR) 16.97 $\mathrm{gm}^{-2} \mathrm{~d}^{-1}$ was observed at 75 DAT in $\mathrm{I}^{\text {st }}$ date of transplanting on July5 $\left(\mathrm{D}_{1}\right)$, followed by $12.97 \mathrm{gm}^{-2} \mathrm{~d}^{-1}$ at 60 DAT. After 75 DAT, CGR decreased up to 105 DAT. At II $^{\text {nd }}$ date of transplanting on July15 $\left(\mathrm{D}_{2}\right)$, maximum crop growth rate (CGR) was observed at 75 DAT $17.90 \mathrm{gm}^{-2} \mathrm{~d}^{-1}$. Similarly in III $^{\text {rd }}$ date of transplanting onJuly25 $\left(\mathrm{D}_{3}\right)$, also maximum CGR $16.13 \mathrm{gm}^{-2} \mathrm{~d}^{-1}$ was recorded at 75 DAT lower than $\mathrm{D}_{1}$ or $\mathrm{D}_{2}$.

The characteristics feature of CGR at different date of transplanting of different varieties has been depicted in fig. 4.2. From the table it was also observed that among the different dates of transplanting $\mathrm{D}_{2}$ attained higher crop growth rate as compare to $\mathrm{D}_{1}$ and $\mathrm{D}_{3}$. From the significant analysis, it was evident that except 75 DAT, crop growth rate at other DAT'S were significant among each other while at 75 DAT non-significant value of CGR was recorded.

Among the varieties for the crop growth rate (CGR) Sarjoo-52 $\left(\mathrm{V}_{1}\right)$ attained maximum value at $\left(16.53 \mathrm{gm}^{-2} \mathrm{~d}^{-1}\right) 75$ DAT, variety NDR-359 $\left(\mathrm{V}_{2}\right)$ attained highest value of CGR $16.87 \mathrm{gm}^{-2} \mathrm{~d}^{-1}$ and $\mathrm{III}^{\mathrm{rd}}$ variety Swarna $\left(\mathrm{V}_{3}\right)$ recorded in maximum crop growth rate 17.60 $\mathrm{gm}^{-2} \mathrm{~d}^{-1}$ at same 75 DAT.

Among the varieties from the table it was also observed that crop growth rate (CGR) in $\mathrm{V}_{3}$ recorded highest $\mathrm{CGR}$ as compare to $\mathrm{V}_{1} \& \mathrm{~V}_{2}$. From the significant analysis, it was evident that except $45 \& 75$ DAT all varieties at rest DAT were significant among each other while at 45 and 75 DAT varieties were non- significant among each other. Higher CGR during 60-75 DAT panicle initiation to flowering stage might be due to higher dry matter partitioning in different plant organs hence higher growth rate.

Relative growth rate $(\mathrm{RGR})\left(\mathrm{mg} / \mathrm{g} /\right.$ day $\left.\times 10^{-2}\right)$ : Relative Growth Rate (RGR) (mg/g/day) of different rice cultivars at different dates of transplanting has been depicted in table 4 . From table it was revealed that relative growth rate (RGR) at $\mathrm{I}^{\text {st }}$ date of transplanting on July $5\left(\mathrm{D}_{1}\right)$, was highest $8.5 \mathrm{mg} / \mathrm{g} /$ day at 30 DAT, subsequently decreased then after at all DAT. Minimum value of RGR $0.39 \mathrm{mg} / \mathrm{g} /$ day was reported at 105 DAT at $\mathrm{I}^{\text {st }}$ date of transplanting $\left(\mathrm{D}_{1}\right)$. Similarly $\mathrm{II}^{\text {nd }}$ date of transplanting on July $15\left(\mathrm{D}_{2}\right)$, relative growth rate (RGR) at 30DAT the RGR value was same $8.5 \mathrm{mg} / \mathrm{g} /$ day as that ofD $_{1}$ with is minimum value $0.38 \mathrm{~g} /$ day at 105 DAT.

Table.1 Days taken to attain different phenophase of rice cultivars at different days after transplanting (DAT)

\begin{tabular}{|c|c|c|c|c|c|c|}
\hline Treatment & \multicolumn{7}{|c|}{ Days after transplanting (DAT) } \\
\hline $\begin{array}{c}\text { Date of } \\
\text { transplanting }\end{array}$ & \multicolumn{7}{|c|}{$\begin{array}{c}\text { Maximum } \\
\text { tillering }\end{array}$} & $\begin{array}{c}\text { Panicle } \\
\text { initiation }\end{array}$ & $\begin{array}{c}\text { Mo(\%) } \\
\text { Flowering }\end{array}$ & Milking & Dough & $\begin{array}{c}\text { Physiological } \\
\text { Maturity }\end{array}$ \\
\cline { 2 - 7 }$\left(\mathbf{D}_{\mathbf{1}}\right)$ & 30 & 58 & 74 & 83 & 92 & 102 \\
\hline $\left.\mathbf{( D}_{\mathbf{2}}\right)$ & 26 & 56 & 72 & 80 & 91 & 106 \\
\hline $\left.\mathbf{( D}_{\mathbf{3}}\right)$ & 25 & 51 & 67 & 74 & 85 & 95 \\
\hline Varieties & 26 & 52 & 67 & 74 & 84 & 98 \\
\hline$\left(\mathbf{V}_{\mathbf{1}}\right)$ & 24 & 48 & 64 & 72 & 82 & 89 \\
\hline$\left(\mathbf{V}_{\mathbf{2}}\right)$ & 31 & 65 & 82 & 91 & 102 & 116 \\
\hline$\left(\mathbf{V}_{3}\right)$ & & & & & \\
\hline
\end{tabular}


Table.2 Linear Growth Rate (LGR) (cm/day) of different rice cultivars at different days of transplanting

\begin{tabular}{|c|c|c|c|c|c|c|}
\hline \multirow{3}{*}{$\begin{array}{c}\text { Treatment } \\
\text { Date of } \\
\text { transplanting }\end{array}$} & \multicolumn{6}{|c|}{ Linear Growth Rate (cm/day) } \\
\hline & \multicolumn{6}{|c|}{ Days after transplanting (DAT) } \\
\hline & 30 & 45 & 60 & 75 & 90 & 105 \\
\hline$\left(\mathbf{D}_{1}\right)$ & 0.74 & 1.79 & 0.85 & 1.01 & 1.21 & 0.35 \\
\hline$\left(\mathbf{D}_{2}\right)$ & 0.74 & 1.81 & 0.87 & 1.03 & 1.22 & 0.36 \\
\hline$\left(\mathbf{D}_{3}\right)$ & 0.73 & 1.54 & 0.81 & 0.87 & 1.13 & 0.32 \\
\hline SEM \pm & 0.019 & 0.045 & 0.022 & 0.023 & 0.028 & 0.008 \\
\hline CD (5\%) & NS & 0.157 & NS & 0.081 & NS & 0.029 \\
\hline \multicolumn{7}{|l|}{ Varieties } \\
\hline$\left(\mathbf{V}_{1}\right)$ & 0.76 & 1.73 & 0.83 & 0.98 & 1.18 & 0.35 \\
\hline$\left(V_{2}\right)$ & 0.70 & 1.83 & 0.92 & 1.06 & 1.25 & 0.37 \\
\hline$\left(\mathbf{V}_{3}\right)$ & 0.75 & 1.58 & 0.78 & 0.85 & 1.09 & 0.32 \\
\hline SEM \pm & 0.014 & 0.032 & 0.016 & 0.018 & 0.020 & 0.006 \\
\hline CD (5\%) & 0.042 & 0.096 & 0.049 & 0.054 & 0.061 & 0.018 \\
\hline
\end{tabular}

Table.3 Crop Growth Rate (CGR) of rice cultivars at different dates of transplanting.

\begin{tabular}{|c|c|c|c|c|c|c|}
\hline Treatment & \multicolumn{6}{|c|}{ Crop Growth Rate (CGR) $\left(\mathrm{gm}^{-2} \mathrm{~d}^{-1}\right)$} \\
\hline \multirow[t]{2}{*}{ Date of transplanting } & \multicolumn{6}{|c|}{ Days after transplanting (DAT) } \\
\hline & 30 & 45 & 60 & 75 & 90 & 105 \\
\hline$\left(\mathbf{D}_{1}\right)$ & 6.37 & 7.87 & 12.97 & 16.97 & 6.23 & 5.28 \\
\hline$\left(\mathbf{D}_{2}\right)$ & 6.77 & 8.53 & 13.97 & 17.90 & 6.60 & 5.64 \\
\hline$\left(\mathbf{D}_{3}\right)$ & 5.73 & 7.30 & 11.83 & 16.13 & 5.60 & 4.88 \\
\hline SEM \pm & 0.14 & 0.20 & 0.33 & 0.44 & 0.15 & 0.13 \\
\hline CD (5\%) & 0.49 & 0.70 & 1.14 & NS & 0.51 & 0.38 \\
\hline \multicolumn{7}{|l|}{ Varieties } \\
\hline$\left(\mathbf{V}_{1}\right)$ & 5.73 & 7.63 & 12.40 & 16.53 & 5.13 & 4.98 \\
\hline$\left(\mathbf{V}_{2}\right)$ & 6.27 & 7.90 & 12.70 & 16.87 & 5.70 & 5.26 \\
\hline$\left(V_{3}\right)$ & 6.87 & 8.17 & 13.67 & 17.60 & 7.60 & 5.62 \\
\hline SEM \pm & 0.14 & 0.16 & 0.28 & 0.33 & 0.14 & 0.12 \\
\hline $\operatorname{CD}(5 \%$ & 0.41 & NS & 0.83 & $\mathrm{NS}$ & 0.41 & 0.41 \\
\hline
\end{tabular}


Table.4 Relative Growth Rate (RGR) of rice cultivars at different dates of transplanting

\begin{tabular}{|c|c|c|c|c|c|c|}
\hline Treatment & \multicolumn{6}{|c|}{ Relative Growth Rate (RGR) (g/day dry matter $\times 10^{-2}$ ) } \\
\hline Date of & \multicolumn{6}{|c|}{ Days after transplanting (DAT) } \\
\hline transplanting & 30 & 45 & 60 & 75 & 90 & 105 \\
\hline$\left(\mathbf{D}_{1}\right)$ & 8.5 & 4.2 & 3.8 & 3.0 & 0.83 & 0.39 \\
\hline$\left(\mathbf{D}_{2}\right)$ & 8.5 & 4.3 & 3.8 & 2.9 & 0.82 & 0.38 \\
\hline$\left(\mathbf{D}_{3}\right)$ & 8.6 & 4.4 & 3.8 & 3.1 & 0.81 & 0.28 \\
\hline SEM \pm & 0.002 & 0.001 & 0.0009 & 0.0007 & 0.0001 & 0.0001 \\
\hline CD (5\%) & NS & NS & NS & NS & NS & NS \\
\hline \multicolumn{7}{|l|}{ Varieties } \\
\hline$\left(\mathbf{V}_{1}\right)$ & 8.2 & 4.4 & 3.9 & 3.1 & 0.73 & 0.29 \\
\hline$\left(\mathbf{V}_{2}\right)$ & 8.3 & 4.3 & 3.8 & 3.0 & 0.77 & 0.36 \\
\hline$\left(\mathbf{V}_{3}\right)$ & 9.1 & 4.2 & 3.9 & 3.0 & 0.97 & 0.40 \\
\hline SEM \pm & 0.001 & 0.0007 & 0.0006 & 0.0005 & 0.0001 & 0.0002 \\
\hline CD (5\%) & 0.005 & NS & NS & NS & 0.0004 & NS \\
\hline
\end{tabular}

Fig. no. 1 Linear growth rate (LGR) of different rice cultivars at different days of transplanting (DAT)

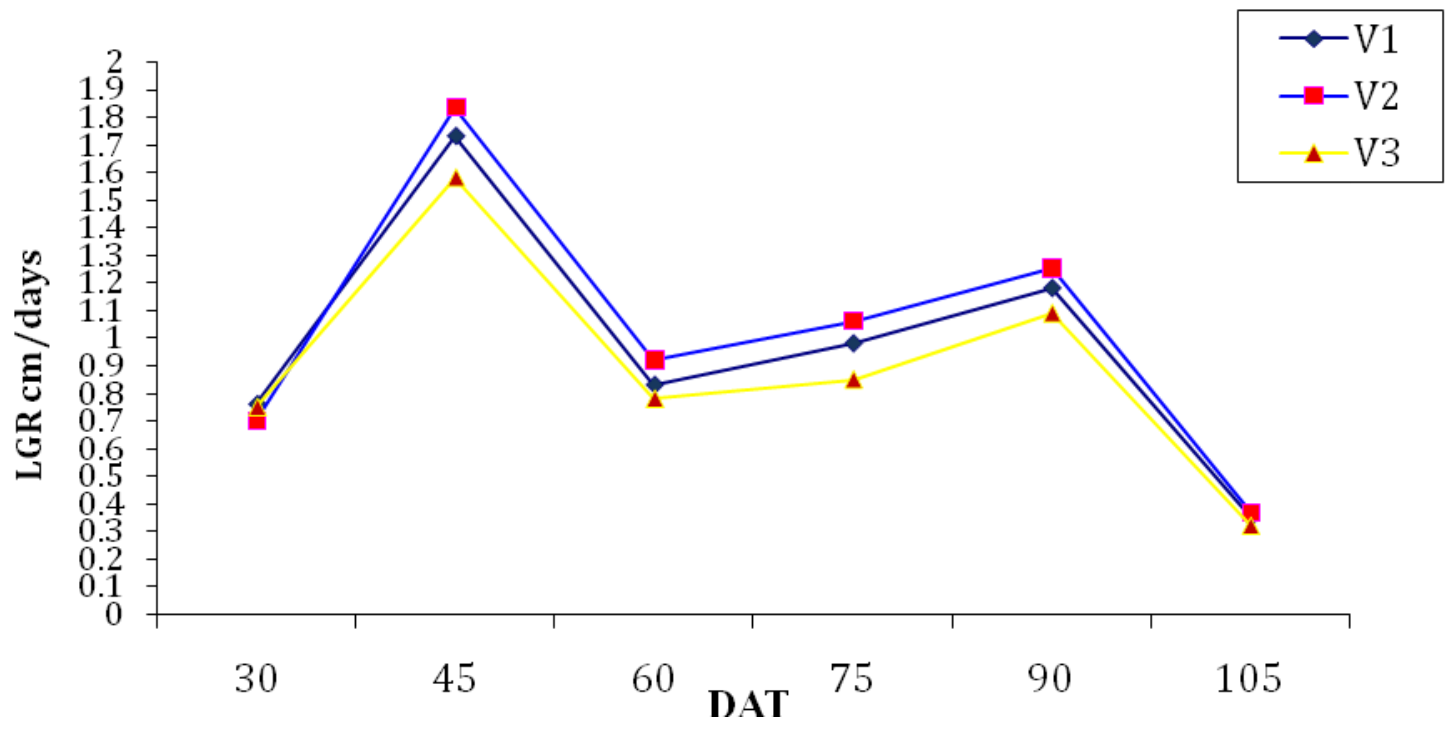




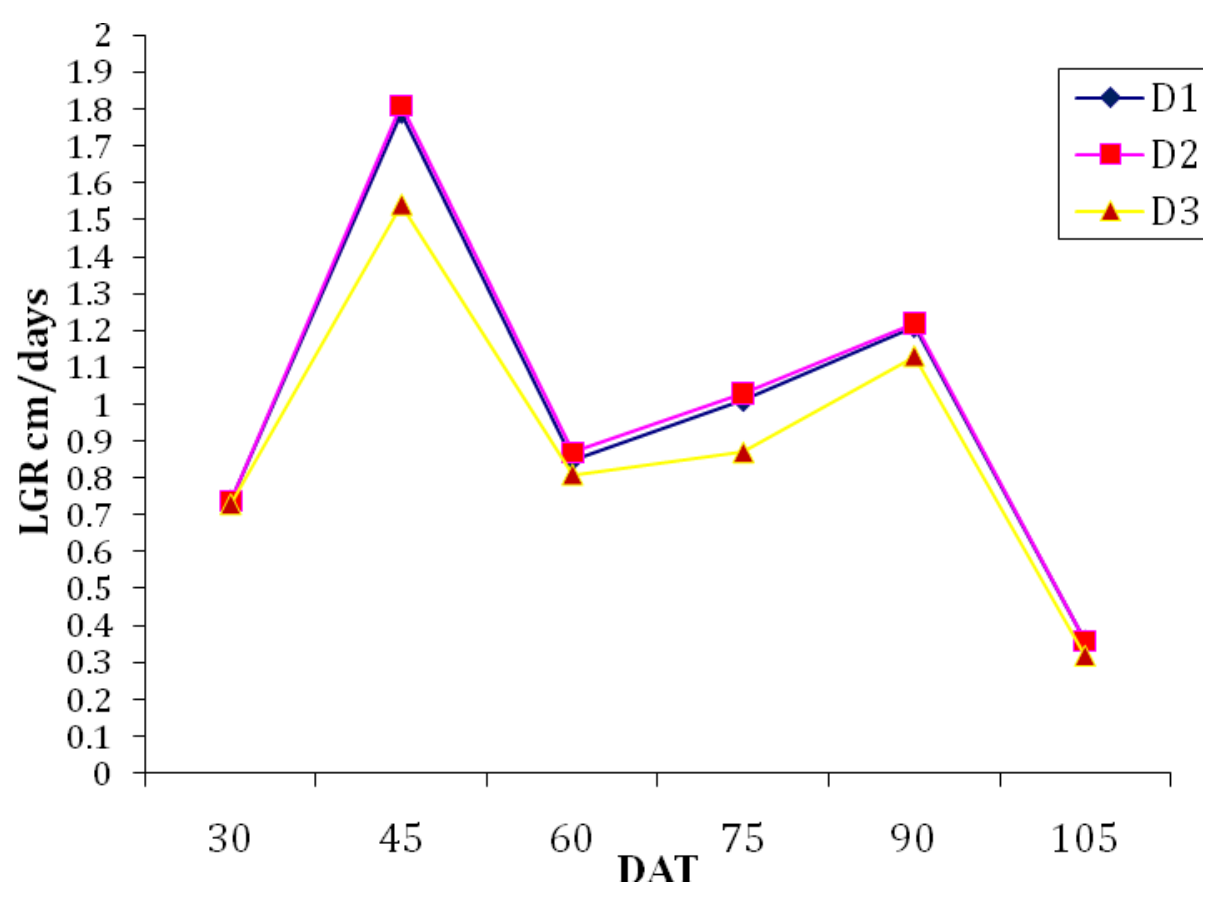

Fig. no. 2 Crop Growth Rate (CGR) of rice varieties at different days of transplanting

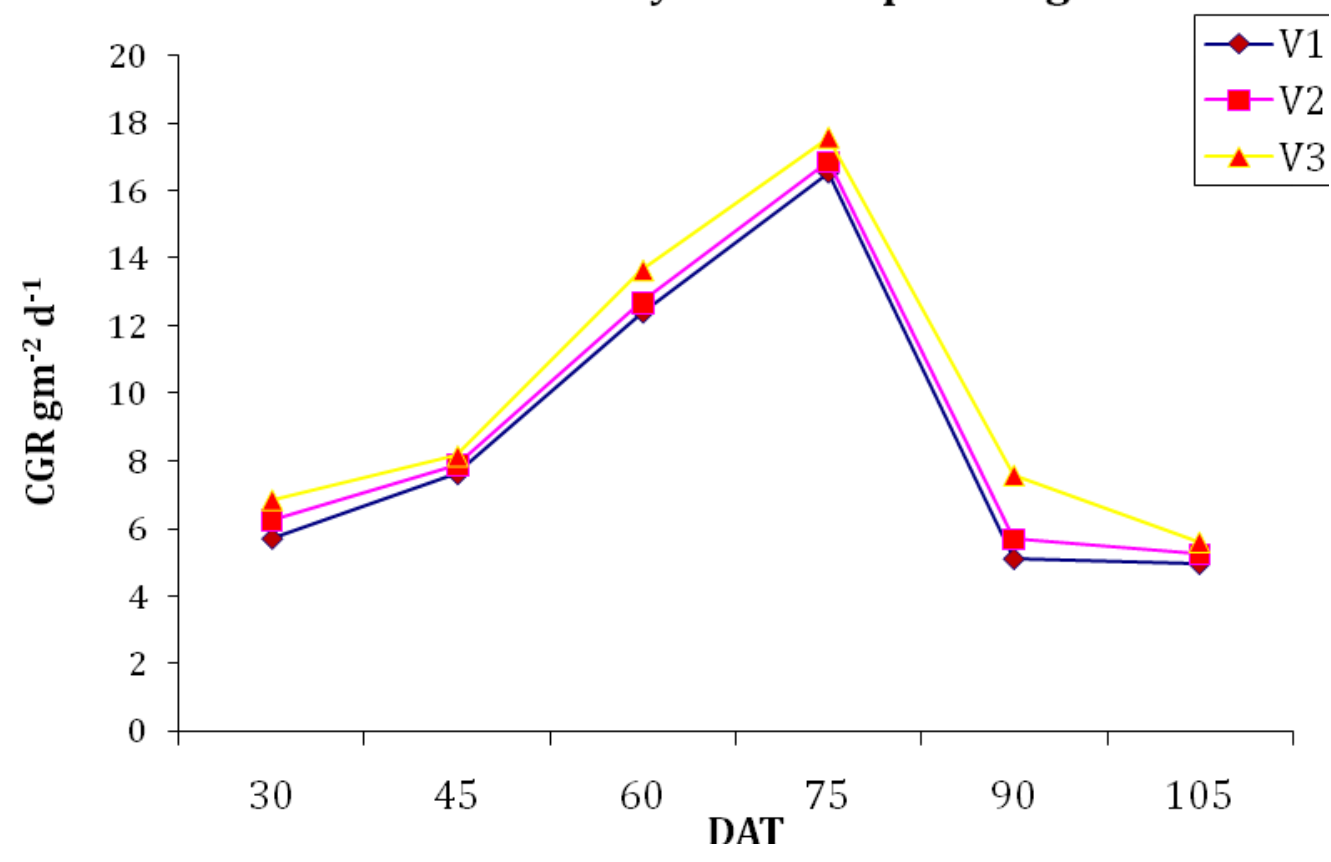


Int.J.Curr.Microbiol.App.Sci (2017) 6(2): 1610-1619

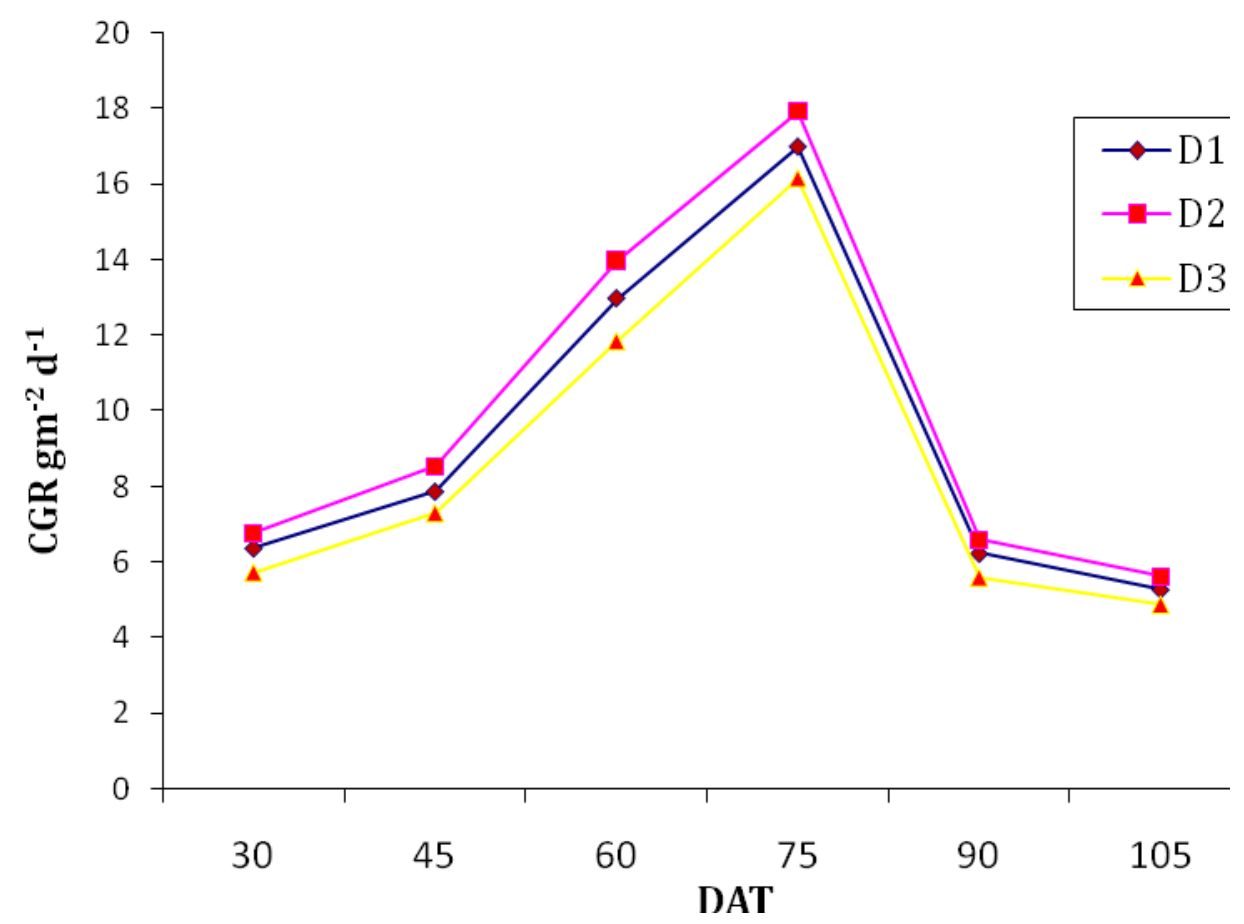

Fig. no. 3 Relative Growth Rate (RGR) of rice cultivars at

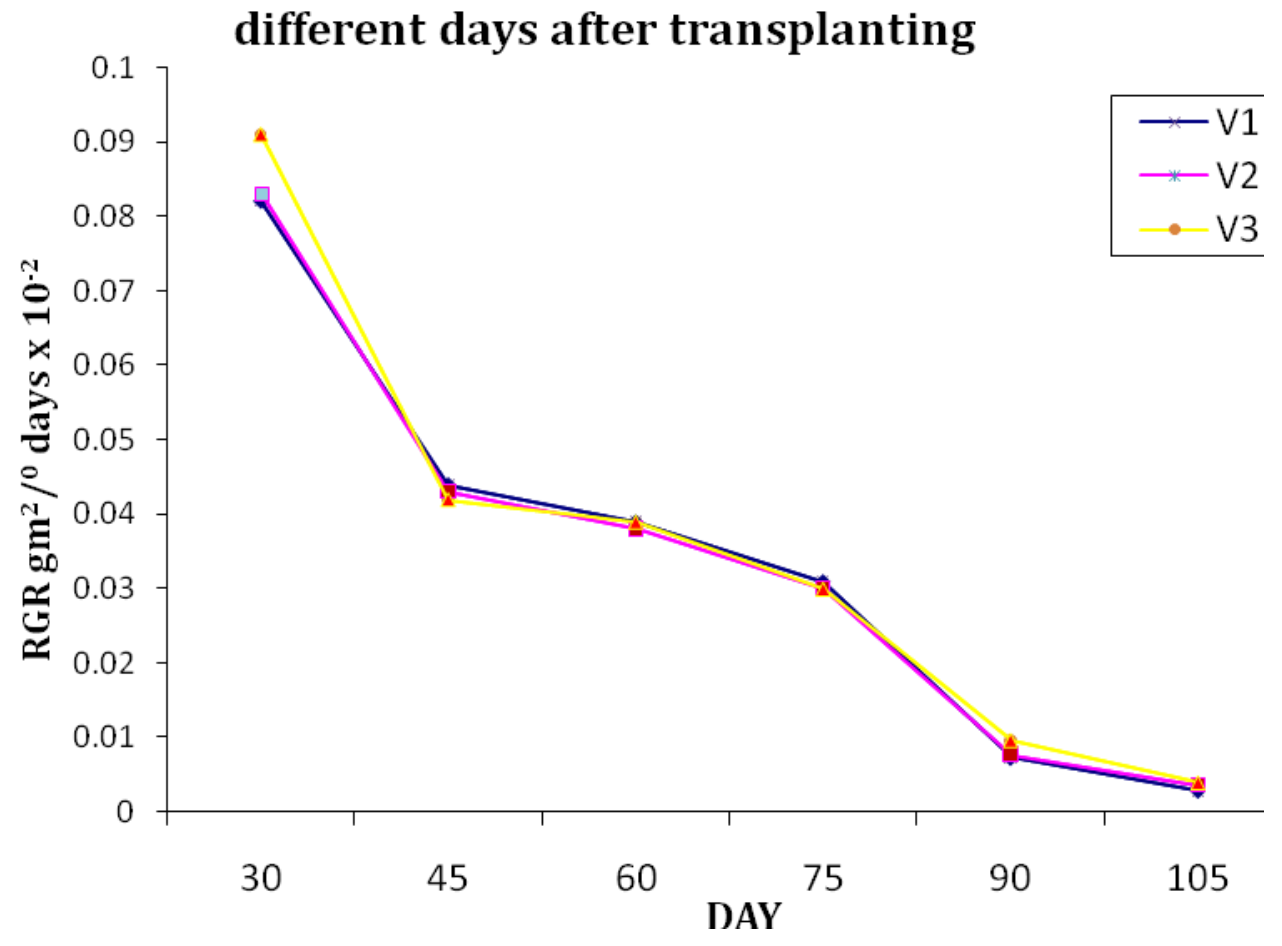




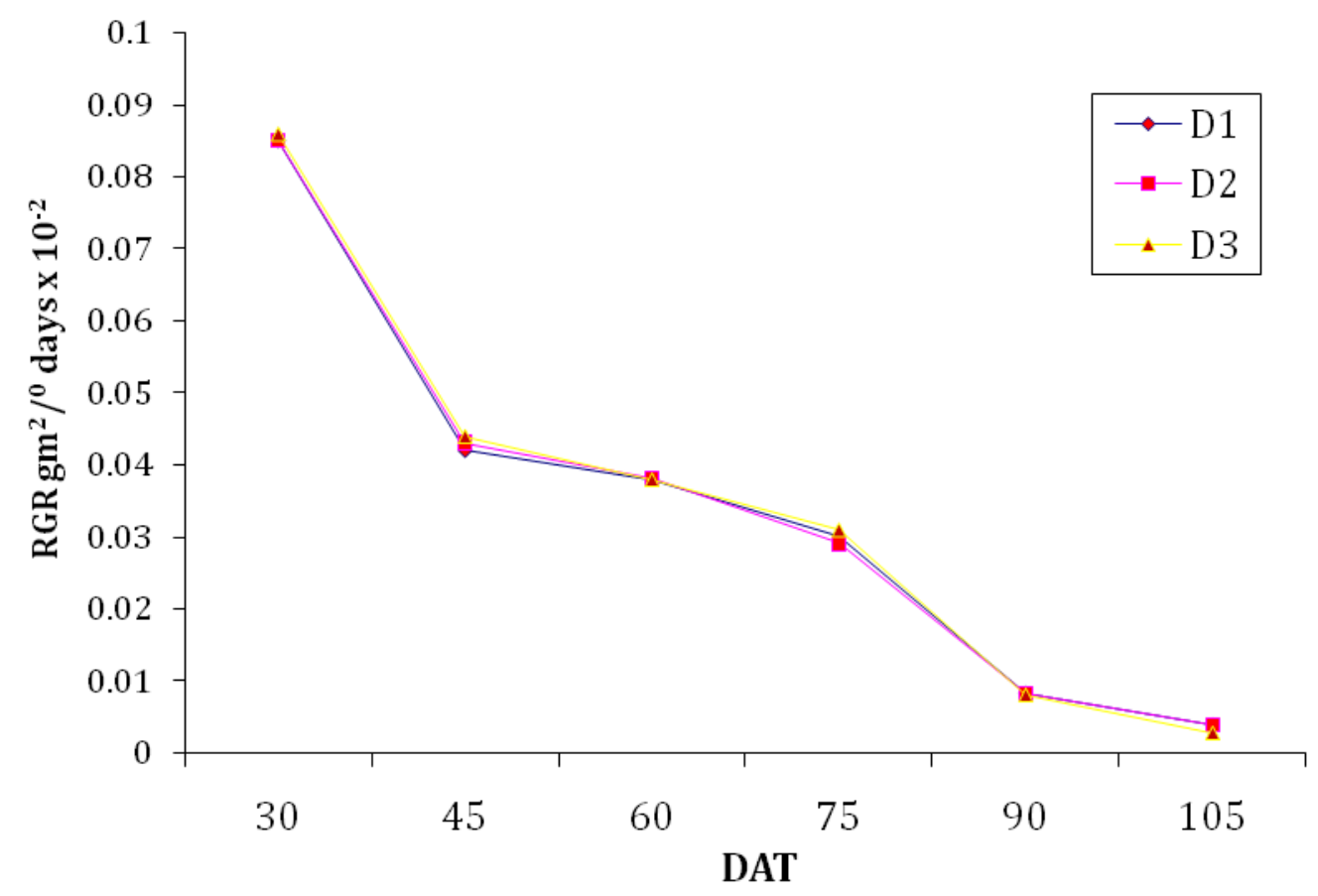

Similarly at III $^{\text {rd }}$ date of transplanting on July $25\left(\mathrm{D}_{3}\right)$, value of RGR at $30,45 \& 60$ DAT were non-significantly higher over $\mathrm{D}_{2}$ but at 90\& 105 DAT the value of RGR at $\mathrm{D}_{3}$ were non-significantly lower. This showed that there is no specific trend in RGR variation in respect of dates of transplanting. From the table it was also observed that different dates of transplanting has achieved nonsignificantly higher relative growth rate (RGR) in $\mathrm{D}_{3}$ than $\mathrm{D}_{2}$ and $\mathrm{D}_{1}$ up to 75 DAT, then after posses lowest value as compared to $\mathrm{D}_{1} \& \mathrm{D}_{2}$. From the significant analysis, it was evident that dates of transplanting were nonsignificant among each other.

Among the varieties for Sarjoo-52 $\left(\mathrm{V}_{1}\right)$, the relative growth rate (RGR) attained highest value at $30 \mathrm{DAT}(8.2 \mathrm{mg} / \mathrm{g} /$ day $)$ and lowest at 105 DAT (0.29 mg/g/day).Variety NDR- 359 $\left(\mathrm{V}_{2}\right)$, attained highest value $8.3 \mathrm{mg} / \mathrm{g} /$ day at 30 DAT and lowest value of RGR 0.36 $\mathrm{mg} / \mathrm{g} /$ day at 105 DAT. Similarly III $^{\text {rd }}$ variety Swarna $\left(\mathrm{V}_{3}\right)$, achieved highest growth rate $9.1 \mathrm{mg} / \mathrm{g} /$ day as compare to $8.3 \mathrm{mg} / \mathrm{g} /$ day in
$\mathrm{V}_{2}$ and $8.2 \mathrm{mg} / \mathrm{g} /$ day $\mathrm{V}_{1}$ at 30 DAT. At 105 DAT also variety $\mathrm{V}_{3}$ maintained the superiorly of RGR and possess highest growth rate 0.40 $\mathrm{mg} / \mathrm{g} /$ day over $\mathrm{V}_{2} 0.36 \mathrm{mg} / \mathrm{g} /$ day and $\mathrm{V}_{1} 0.29$ $\mathrm{mg} / \mathrm{g} /$ day. From the significant analysis, it was evident that at $30 \mathrm{DAT}$, and $90 \mathrm{DAT}$ varieties were significant among each other while at rest DAT, 45 DAT, 60 DAT, 75 DAT and 105 DAT varieties were nonsignificant among each other.

It is concluded that present study in different dates of transplanting (DAT), maximum growth to the $\mathrm{II}^{\text {nd }}$ dates of transplanting (15 July) and suitable varieties of NDR-359. Hence for linear growth rate (LGR) and crop growth rate (CGR) of maximum on II $^{\text {nd }}$ dates of transplanting (15 July), variety is NDR359.

\section{References}

Baker, J.T., Allen, L.H., Boote, K.J. 1992. Temperature effects on rice at elevated CO2 concentration. J. Exp. Bot., 43: 
959-964.

Neue, H.U. and Sass, R. 1994. Trace gas emissions from rice fields. In: Prinn RG (ed) Global atmospheric-biospheric chemistry, Plenum Press, NewYork. pp119- 148.

Raju, N.S., Senguttuvel, P., Voleti, S.R., Prasad, A.S.H., Bhadana, V.P., Revathi, P., Kemparaju, K.B., Chandran, S.R., Singh, A.K., Rao, P.K., Rani, N.S., and Viraktamath, B.C. 2013 Stability analysis of flowering and yield traits to high temperature stress adopting different planting dates in rice $(O$. sativa L.). Int. J. Agri. Res., 8(3):137-148.

Redford, P.J. 1667. Growth analysis formula their use and abuse crop, Sci., 7: 171175.

Watson, D.J. 1947. Comparative physiological studies on the growth of field. I. Variation in net assimilation rats and leaf area between species and varieties, and within and between years. Ann. Bot. (N.S.), 11: 41-76.

\section{How to cite this article:}

Rajan Chaudhari, Ashish Singh S.R. Mishra A.K. Singh and A.N. Mishra. 2017. Study of Phasic Development and Growth Attributes of Rice Cultivars at Variable Weather Condition. Int.J.Curr.Microbiol.App.Sci. 6(2): 1610-1619. doi: http://dx.doi.org/10.20546/ijcmas.2017.602.179 